\title{
Development of Silicon Solar Cells and Photovoltaic Modules in Brazil: Analysis of a Pilot Production
}

\author{
Adriano Moehlecke*, Izete Zanesco \\ Solar Energy Technology Nucleus, Faculty of Physics, \\ Pontifical Catholic University of Rio Grande do Sul - PUCRS, \\ Av. Ipiranga, 6681, P. 96A, TECNOPUC, CEP 90619-900, Porto Alegre, RS, Brazil
}

Received: March 7, 2012; Revised: April 21, 2012

\begin{abstract}
Brazil is a country that receives a large amount of solar radiation. Moreover, high quality quartz mines has been found in its territory and the country has well-established metallurgical grade silicon industries. However, PV technology is not used in large scale and there are no active solar cell fabs. In this context, a pilot plant to develop industrial PV technology was carried out in a Brazilian university combining education, research and industrial development. Silicon solar cell processes based on low cost chemicals and gases as well as gettering mechanisms were developed and more than 12,000 solar cells were fabricated, achieving efficiencies up to $16 \%$, and two hundred photovoltaic modules were produced and characterized.
\end{abstract}

Keywords: pilot plant, solar cells, photovoltaic modules

\section{Introduction}

Brazil is one of the countries with high use of renewable energy in the world due to the widespread use of hydropower that represents more than $74 \%$ of total electrical energy supply ${ }^{1}$. In spite of that, new renewable energies had to be introduced in the energy matrix due to the growth of the Brazilian economy and the public resistance to hydroelectric plants that inundate large areas of rain forest. In 2003, wind energy was the first "new" renewable energy to have a federal program of incentives, called PROINFA (Brazilian Renewable Energy Incentive Program) ${ }^{2}$. Nowadays, there is an established market for wind power, with several companies producing equipments for all the value chain. On the other hand, photovoltaic (PV) technology continued to be used mainly for stand-alone systems.

In the last two decades, around $30 \mathrm{MW}$ of PV systems were installed in Brazil, mainly in the framework of Brazilian governmental programs to promote rural electrification, such as PRODEEM (Program for Energetic Development of States and Municipalities) and the program Light for All (Luz para Todos). During the last decade, several small PV systems were connected to the grid, most of them in universities and research centers. Recently, a regulation for grid connected PV systems was implemented by ANEEL (Brazilian Agency for Electric Energy). In 2011, the first $1 \mathrm{MW}$ power plant was installed in the Northwest of Brazil and the second $1 \mathrm{MW}$ will be installed in a roof of a state energy company in South of the country in the next years. There is a lack of an industrial park in spite of the high levels of incoming solar irradiation, the abundance of the raw material (quartz and metallurgical grade silicon) and the residential electricity rates similar to those of some European countries. Nevertheless, EPIA (European Photovoltaic

*e-mail: moehleck@pucrs.br
Industry Association) estimates a Brazilian market of $3200 \mathrm{MW}$ in 2020 considering a moderate scenario ${ }^{3}$.

In Europe, since the 80's the development of industrial processes of solar cells has been carried out at IMEC (Interuniversity MicroElectronics Center) ${ }^{4}$. From the research \& development activities of this center, several success PV companies were spin-off. In 2005, the ISE (Fraunhofer Institute for Solar Energy Systems) published the implementation of a research unit for applied $R \& D$ for silicon solar cell production, called Photovoltaic Technology Evaluation Center (PV-TEC) ${ }^{5}$. The center was created to support the German and European photovoltaic industry with large scale research. In Asia, the Solar Energy Research Institute of Singapore (SERIS), established in 2008, has similar mission: "conducts industry-oriented research and development as well as use - inspired basic research in the field of solar energy conversion". In the labs of SERIS new solar cell structures have been developed as well as pilot lines to process silicon solar cells and thin film modules. Besides, solar energy systems are studied and PV modules can be certified according to the standards of the International Electrotechnical Commission (IEC). In the United States of America, National Renewable Energy Laboratory (NREL) launched the SunShot Incubator Program in September, 2011, aiming to advance in new manufacturing processes and products. This incubator program was an expansion of the PV Technology Incubator Program of the Departament of Energy ${ }^{7}$.

The aim of this paper is to present the development and results of a PV cell and module pilot plant established in Brazil in order to promote rapid technology transferring from lab scale to the production lines. More than 12,000 silicon solar cells were fabricated by using two process sequences and modules were fabricated and characterized under 
standard conditions. The main innovations of the pilot plant are: a) technology: baseline processes that use low cost chemicals and rely on gettering to enhance bulk lifetime; b) ambient: at the first time a complete production line, from cells to module was established in a university campus, allowing preparation of qualified human resources for PV industries; c) management: R\&D project was managed by a committee composed of representatives of all companies, agencies and university involved.

The pilot plant was established in 2005 and all the equipments and facility were implemented in the following years. Processes were optimized and, in 2009, the cells and modules were produced. The pilot plant was supported by the Brazilian Ministry of Science and Technology and the financing agency FINEP as well as three energy companies (CEEE-GT, Eletrosul and Petrobras).

\section{Infrastructure of the Pilot Plant}

The pilot plant was installed in a total area of $950 \mathrm{~m}^{2}$ of which $212 \mathrm{~m}^{2}$ were clean room labs (10000 class, ISO7). Labs are equipped with industrial and automated equipments to reproduce on a large scale the lab devices as well as to develop R\&D activities focused on high efficiency Si solar cells and modules. The clean room area is split in eight labs and it was designed to produce Si solar cells with different metallization techniques (screen-printing, electroless, e-beam metal evaporation) and different ways to diffuse impurities (conventional quartz tube, rapid thermal and belt furnaces). Besides solar cell fabrication facility, PV modules can be assembled in a semi-automatic line and can be characterized in a standard flash simulator as well as submitted to several tests according of IEC sequences. Figure 1 shows three labs used in the pilot plant.

\section{Solar Cell Fabrication}

\subsection{Processes}

Two processes were developed, one to produce $\mathrm{n}^{+} \mathrm{pn}^{+}$silicon solar cells and other to produce $\mathrm{n}^{+} \mathrm{pp}^{+}$cells. The $\mathrm{n}^{+} \mathrm{pn}^{+}$solar cell is a simple device based on one thermal step (phosphorus diffusion) and with an Al/Ag metal grid that perforates rear $n^{+}$region. This structure was one of the workhorses of industries that use screen-printing to deposit metal $\operatorname{grid}^{9,10}$. Processes to obtain $\mathrm{n}^{+} \mathrm{pp}^{+}$solar cells with aluminum back surface field (BSF) have been implemented in production lines allowing the achievement of efficiencies above $16 \%$. Combining BSF region, selective emitter and narrow metal lines, $18.8 \%$ efficient solar cells can be produced with monocrystalline silicon wafers ${ }^{11}$. Figure 2 presents both structures and Figure 3 summarizes the sequences of the solar cell processes.

The starting material was Czochralski (CZ) silicon, p-type, boron doped, 1-10 ohms.cm, 4" round wafers, $<100>$ orientation and $300 \mu \mathrm{m}$ thick. We used 4" round wafers instead of the standard pseudo-square ones because this kind of wafer was very hard to acquire during the silicon shortage by 2007-2008. All the processing steps were optimized. Low grade chemicals and gases were used as proposed by Moehlecke et al. ${ }^{8}$. The process to fabricate $\mathrm{n}^{+} \mathrm{pn}^{+}$

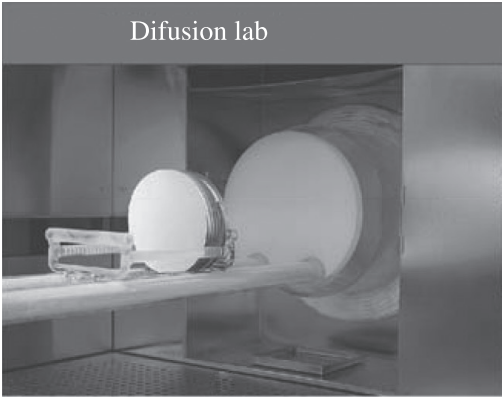

(a)



(b)
Characterization lab

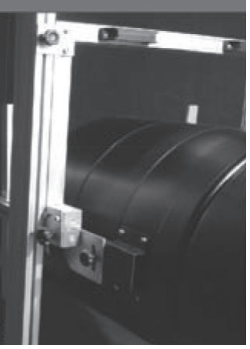

(c)

Figure 1. Details of three labs in the facility with $950 \mathrm{~m}^{2}$ of specialized laboratories: a) phosphorus diffusion furnace, b) automatic tabber\&stringer and c) solar simulator.



(a)

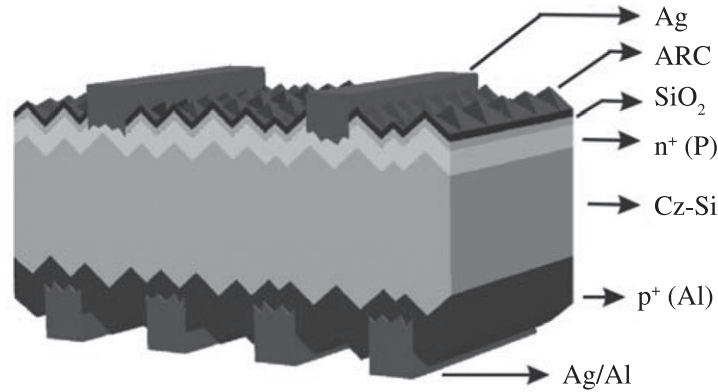

(b)

Figure 2. Solar cell structures: a) $\mathrm{n}^{+} \mathrm{pn}^{+}$, without back surface field (BSF) and b) $\mathrm{n}^{+} \mathrm{pp}^{+}$, with aluminum $\mathrm{BSF}-\mathrm{p}^{+}(\mathrm{Al})$. Cz-Si means Czochralski-grown monocrystalline silicon and ARC signifies antireflection coating. 
solar cells was based on: texture etch with $\mathrm{KOH}$ solution, RCA cleaning 9 (a standard wafer cleaning developed by the Radio Corporation of America), phosphorus diffusion based on $\mathrm{POCl}_{3}$, phosphorus silicate glass (PSG) removal and $\mathrm{RCA}$ cleaning, $\mathrm{TiO}_{2}$ antireflecting coating deposition, screen-printing of metal grid and laser edge isolation.

Cells with $\mathrm{n}^{+} \mathrm{pp}^{+}$structure were processed following the steps: texture etch, RCA cleaning, oxide growth, oxide etching from the frontal face, RCA cleaning, phosphorous diffusion, PSG removal and chemical cleaning, aluminum deposition by e-beam evaporation, Al diffusion, oxide growth, $\mathrm{Ag}$ and $\mathrm{Ag} / \mathrm{Al}$ screen-printing and edge isolation. This process sequence was the first approach to introduce

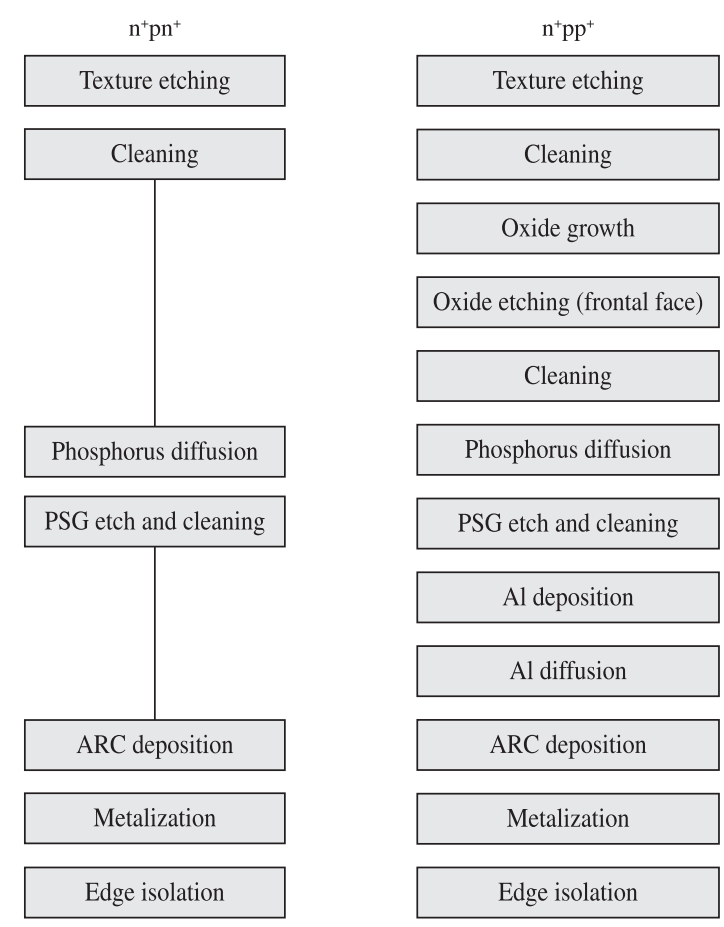

Figure 3. Fabrication process sequences used to produce silicon solar cells.

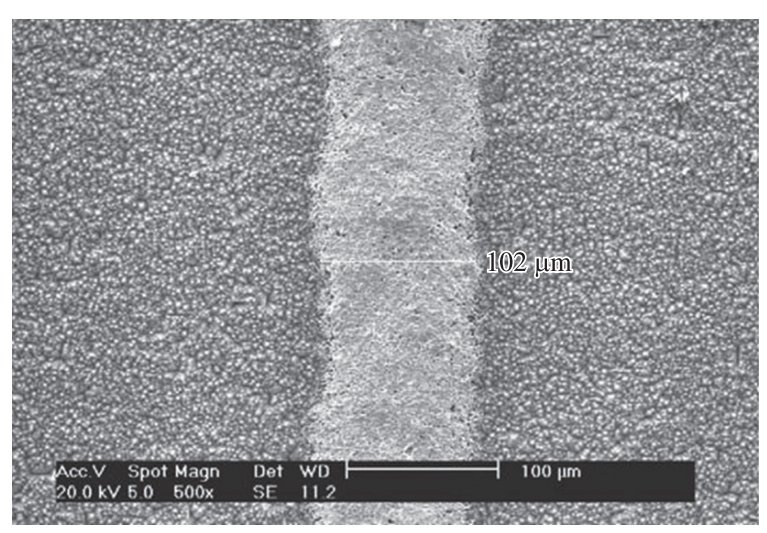

(a)
Al-BSF in the pilot line taking into account earlier results obtained with small area devices ${ }^{8}$.

From 4 wafers, $80 \mathrm{~mm} \times 80 \mathrm{~mm}$ pseudo-square cells were obtained after removing four circular segments by using a laser-cutter system. Cells had area of $61.58 \mathrm{~cm}^{2}$, with a standard two-busbars metal grid. The dimensions of $80 \mathrm{~mm} \times 80 \mathrm{~mm}$ were obtained taking into account the best filling and efficiency of PV module with 36 cells distributed in four strings.

Phosphorus diffusion was implemented starting from $\mathrm{POCl}_{3}$ and it was experimentally optimized taking into account the best sheet resistance related to temperature, time and gas flows as well as the electrical characteristics of solar cells fabricated with different surface passivation for $\mathrm{n}^{+} \mathrm{pn}^{+}$and $\mathrm{n}^{+} \mathrm{pp}^{+}$cells, independently.

Concerning antireflection coating (ARC), $\mathrm{TiO}_{2}$ thin film was used instead of the PV industry standard $\mathrm{SiN}_{\mathrm{x}}$, because high purity silane supply chain was not established in Brazil. For $\mathrm{TiO}_{2}$ films, the impact of metal firing step was analyzed and considered in this pilot production ${ }^{13}$. For example, we observed that the reflectance of ARC was enhanced after the firing of metal pastes and the wavelength related to the minimum reflectance was shifted to shorter wavelengths. Therefore, thicker ARCs have to be deposited according thermal step of firing metal pastes.

The metal grids were deposited by screen-printing and we used standard pastes, PV156 (Ag) and PV202 (Ag-Al) supplied by DuPont. Local suppliers of screens were trained and $100 \mu \mathrm{m}$ wide fingers were obtained in production, with thickness of $17-18 \mu \mathrm{m}$, as Figure 4 illustrates.

\subsection{Solar cell characterization and classification}

After optimizing the process sequences, 5,715 $\mathrm{n}^{+} \mathrm{pn}^{+}$ solar cells and $6,970 \mathrm{n}^{+} \mathrm{pp}^{+}$devices were fabricated and characterized. In the Figure 5 the $80 \mathrm{~mm} \times 80 \mathrm{~mm}$ pseudo-square cells are presented. All devices were characterized under standard conditions $\left(100 \mathrm{~mW} . \mathrm{cm}^{-2}\right.$, AM1.5G and $25{ }^{\circ} \mathrm{C}$ ) in a solar simulator calibrated with similar cells previously measured at CalLab - FhG-ISE (Fraunhofer-Institut für Solare Energiesysteme), Germany.

In Figure 6 the I-V characteristics of $\mathrm{n}^{+} \mathrm{pn}^{+}$cells and $\mathrm{n}^{+} \mathrm{pp}^{+}$cells are compared. Cell 2 and cell 4 were measured

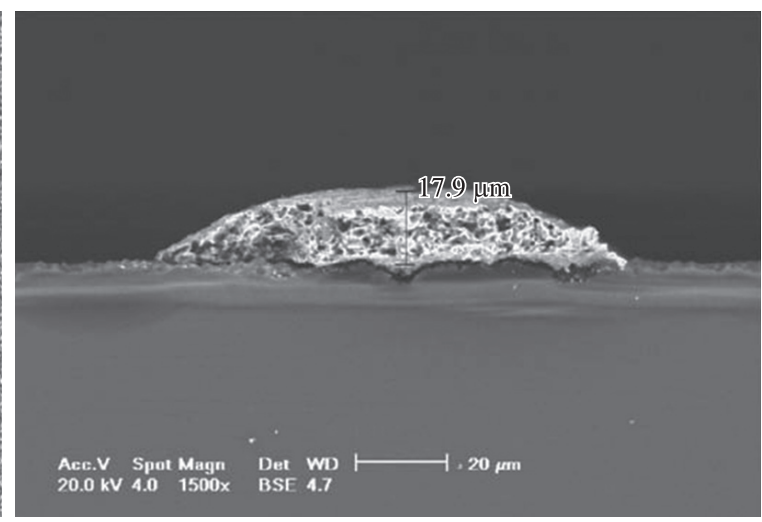

(b)

Figure 4. Screen-printed Ag finger on silicon solar cell: a) top view, pointing out the metal finger width ( $\cong 100 \mu \mathrm{m})$ and b) cross section view, showing the finger thickness $(\cong 18 \mu \mathrm{m})$. 
at CalLab - FhG-ISE and cell 1 and cell 3 were the best efficiency $(\eta)$ achieved of $16.1 \%$ and $13.4 \%$ for cells with and without back surface field, respectively. Fill factors of around 0.78 were obtained as a result of the optimized screen-printing metal grid. The difference between both structures is clearly observed in open-circuit voltage $\left(\mathrm{V}_{\mathrm{OC}}\right)$ and short-circuit current density $\left(\mathrm{J}_{\mathrm{SC}}\right)$ due to the effect of $\mathrm{BSF}$ in $\mathrm{n}^{+} \mathrm{pp}^{+}$cells, enhancing both parameters. External quantum efficiency (EQE), presented in Figure 7, confirms the impact of BSF by the best sensitivity of $\mathrm{n}^{+} \mathrm{pp}^{+}$cells for longer wavelengths. Besides, a small enhancement in

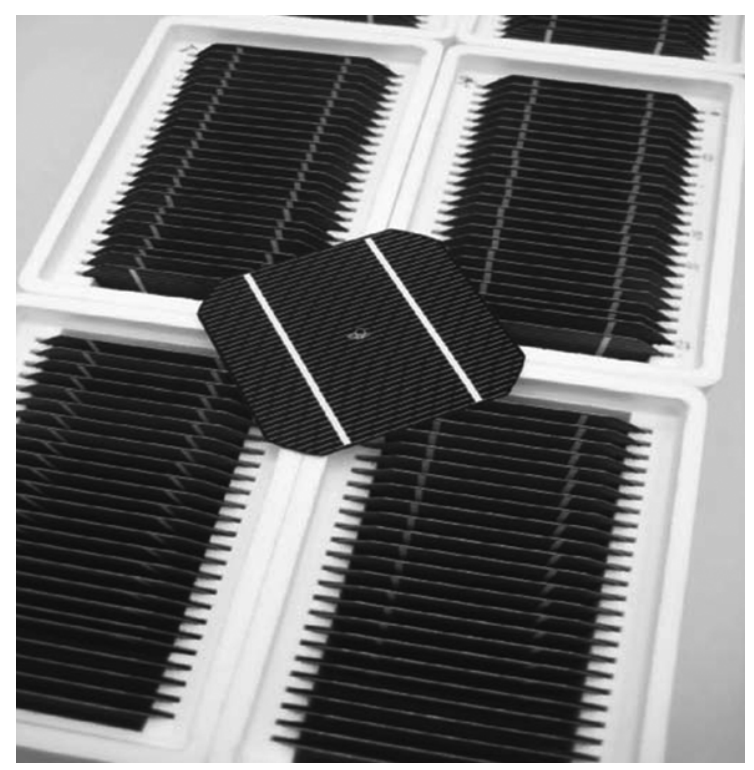

Figure 5. Silicon solar cells fabricated in the pilot line.

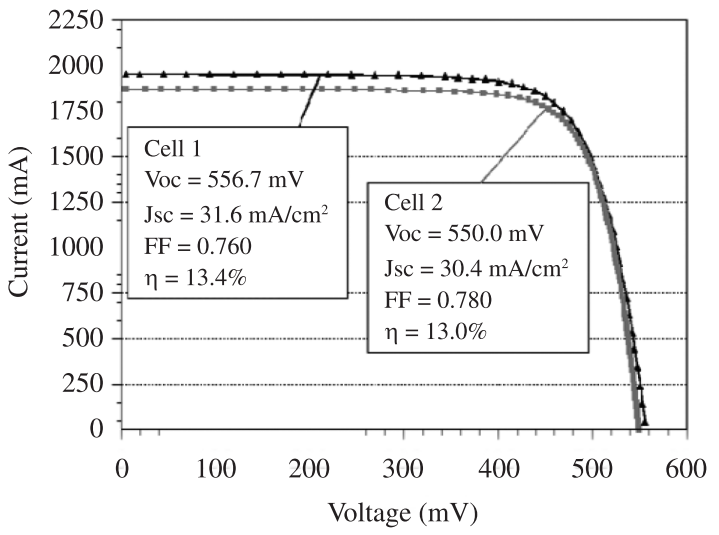

(a) shorter wavelengths presented in cells with BSF stems from the better front surface passivation and shallower emitter.

Cells were classified in four categories concerning $\mathrm{J}_{\mathrm{SC}}$ and fill factor (FF). This classification is currently used because cells are connected in series in most PV modules. Moreover, the FF was used to select cells bearing in mind that it indicates problems arising from metallization. For instance, class D cells with very low FF are not suitable to produce photovoltaic modules. Table 1 resumes the different classes and Table 2 and 3 present the average electrical characteristics of cells without and with BSF, respectively. In the Figure 8 we present the distribution of cells according to the classes.

Cells processed with only one thermal step $\left(\mathrm{n}^{+} \mathrm{pn}^{+}\right.$ devices) presented average efficiency of $(12.7 \pm 0.4) \%$ for $89.4 \%$ of the cells, taking into account the A, B and C class. The $\mathrm{J}_{\mathrm{SC}}$ is reduced from class A to $\mathrm{C}$, but the FF slightly increases, keeping similar efficiency for the three classes.

By using $\mathrm{n}^{+} \mathrm{pp}^{+}$structure, cells achieved efficiencies as high as $16.1 \%$, but average values vary from $(14.9 \pm 0.4) \%$ for class A to $(14.0 \pm 0.6) \%$ for class $\mathrm{C}$. The devices classified as class B presented the efficiency of $(14.7 \pm 0.5) \%$. For cells with BSF, $90.2 \%$ devices were classified as class A, $\mathrm{B}$ and $\mathrm{C}$. Wider range of efficiencies observed in $\mathrm{n}^{+} \mathrm{pp}^{+}$cells is mainly due to the variation of the short-circuit current. We attributed this dispersion to the lack of uniformity of the minority carrier diffusion length in these cells, as Figure 9 shows. This result was obtained from LBIC (light beam induced current) measurements carried out with WT1000-PV equipment, from Semilab. The wider range of effective lifetime (bulk and BSF), from batch to batch, may also explain this behavior for $\mathrm{n}^{+} \mathrm{pp}^{+}$cells. Spectral reflectance measurements confirm that the spreading in $\mathrm{J}_{\mathrm{SC}}$

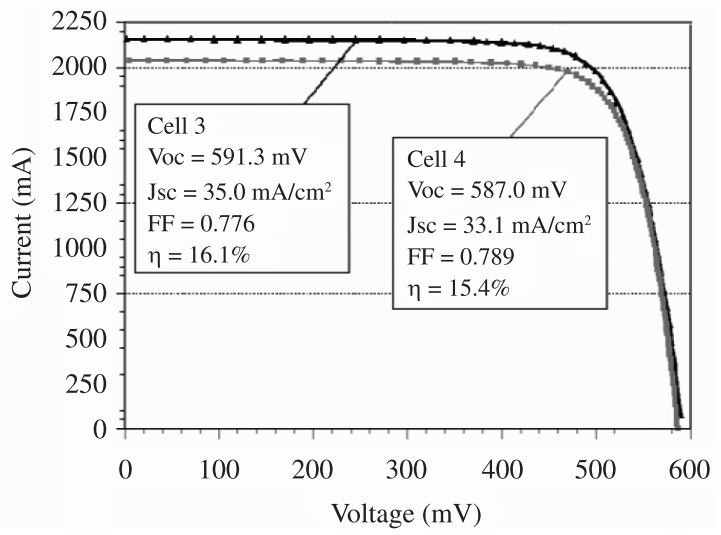

(b)

Figure 6. Electrical characteristics at standard conditions of a) $\mathrm{n}^{+} \mathrm{pn}^{+}$and b) $\mathrm{n}^{+} \mathrm{pp}^{+}$solar cells. Cell 2 and cell 4 were measured at CalLab - FhG-ISE, Germany.

Table 1. Solar cell classification concerning the $\mathrm{J}_{\mathrm{SC}}$ and FF.

\begin{tabular}{ccc}
\hline Class & $\mathbf{n}^{+} \mathbf{p n}^{+}$solar cells (without BSF) & $\mathbf{n}^{+} \mathbf{p p}^{+}$solar cells (with Al-BSF) \\
\hline $\mathrm{A}$ & $\mathrm{FF}>0.7$ and $\mathrm{J}_{\mathrm{SC}} \geq 31.5 \mathrm{~mA} \cdot \mathrm{cm}^{-2}$ & $\mathrm{FF}>0.7$ and $\mathrm{J}_{\mathrm{SC}} \geq 34 \mathrm{~mA} \cdot \mathrm{cm}^{-2} ;$ \\
$\mathrm{B}$ & $\mathrm{FF}>0.7$ and $31 \mathrm{~mA} \cdot \mathrm{cm}^{-2}<\mathrm{J}_{\mathrm{SC}}<31.5 \mathrm{~mA} \cdot \mathrm{cm}^{-2}$ & $\mathrm{FF}>0.7$ and $33.2 \mathrm{~mA}^{-2}<\mathrm{J}_{\mathrm{SC}}<34 \mathrm{~mA}_{\mathrm{m}} \mathrm{cm}^{-2}$ \\
$\mathrm{C}$ & $\mathrm{FF}>0.7$ and $\mathrm{J}_{\mathrm{SC}} \leq 31 \mathrm{~mA} \cdot \mathrm{cm}^{-2}$ & $\mathrm{FF}>0.7$ and $\mathrm{J}_{\mathrm{SC}} \leq 33.2 \mathrm{~mA} \cdot \mathrm{cm}^{-2}$ \\
$\mathrm{D}$ & $\mathrm{FF}<0.7$ & $\mathrm{FF}<0.7$ \\
\hline
\end{tabular}


is not due to surface texture or ARC. Moreover, we can observe that aluminum BSF allows the production of cells with $\mathrm{V}_{\mathrm{OC}}\left(\right.$ of $25 \mathrm{mV}$ ) and $\mathrm{J}_{\mathrm{SC}}\left(\right.$ of $1.5 \mathrm{~mA} \cdot \mathrm{cm}^{-2}$ ) higher than those obtained in $\mathrm{n}^{+} \mathrm{pn}^{+}$cells.

Considering the cell class A, B and $\mathrm{C}$ as well as the wafer breakage of $4 \%$ for $\mathrm{n}^{+} \mathrm{pn}^{+}$process and $5 \%$ for $\mathrm{n}^{+} \mathrm{pp}^{+}$ one in the pilot production, the yields were similar for both

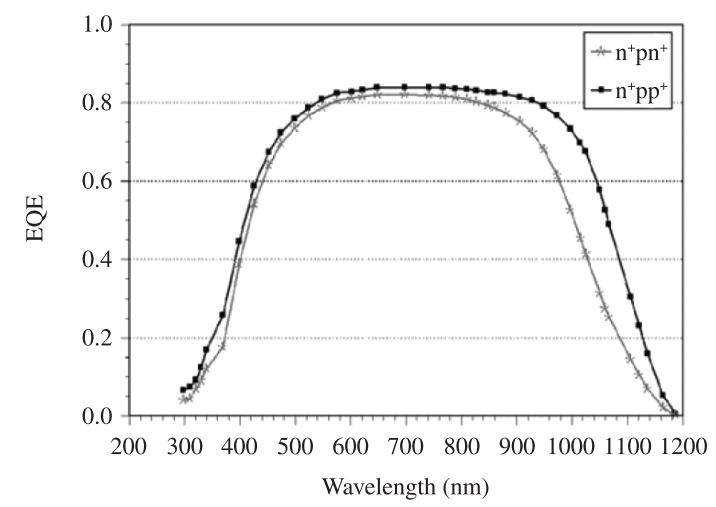

Figure 7. External quantum efficiency of $\mathrm{n}^{+} \mathrm{pn}^{+}$and $\mathrm{n}^{+} \mathrm{pp}^{+}$silicon solar cells. Measurements were performed by CalLab - FhG-ISE.

Table 2. Average electrical characteristics of the $\mathrm{n}^{+} \mathrm{pn}^{+}$solar cells.

\begin{tabular}{ccccc}
\hline Class & $\mathbf{V}_{\text {OC }}(\mathbf{m V})$ & $\mathbf{J}_{\text {SC }}\left(\mathbf{m A . c m}{ }^{-2}\right)$ & $\mathbf{F F}$ & $\eta(\boldsymbol{\%})$ \\
\hline A & $549 \pm 6$ & $31.6 \pm 0.2$ & $0.73 \pm 0.02$ & $12.7 \pm 0.4$ \\
B & $548 \pm 6$ & $31.3 \pm 0.2$ & $0.73 \pm 0.02$ & $12.7 \pm 0.4$ \\
C & $548 \pm 5$ & $30.8 \pm 0.2$ & $0.75 \pm 0.02$ & $12.7 \pm 0.4$ \\
D & $549 \pm 3$ & $31.4 \pm 0.3$ & $0.68 \pm 0.03$ & $11.7 \pm 0.6$ \\
\hline
\end{tabular}

Table 3. Average electrical characteristics of the $\mathrm{n}^{+} \mathrm{pp}^{+}$solar cells.

\begin{tabular}{ccccc}
\hline Class & $\mathbf{V}_{\mathbf{O C}}(\mathbf{m V})$ & $\mathbf{J}_{\mathbf{S C}}\left(\mathbf{m A . \mathbf { c m } ^ { - 2 }}\right)$ & $\mathbf{F F}$ & $\eta(\boldsymbol{\%})$ \\
\hline $\mathrm{A}$ & $575 \pm 6$ & $33.9 \pm 0.3$ & $0.75 \pm 0.01$ & $14.9 \pm 0.4$ \\
$\mathrm{~B}$ & $574 \pm 8$ & $33.2 \pm 0.4$ & $0.76 \pm 0.02$ & $14.7 \pm 0.5$ \\
$\mathrm{C}$ & $565 \pm 8$ & $32.0 \pm 0.6$ & $0.74 \pm 0.02$ & $14.0 \pm 0.6$ \\
$\mathrm{D}$ & $562 \pm 5$ & $31.6 \pm 0.7$ & $0.61 \pm 0.04$ & $11.2 \pm 0.9$ \\
\hline
\end{tabular}

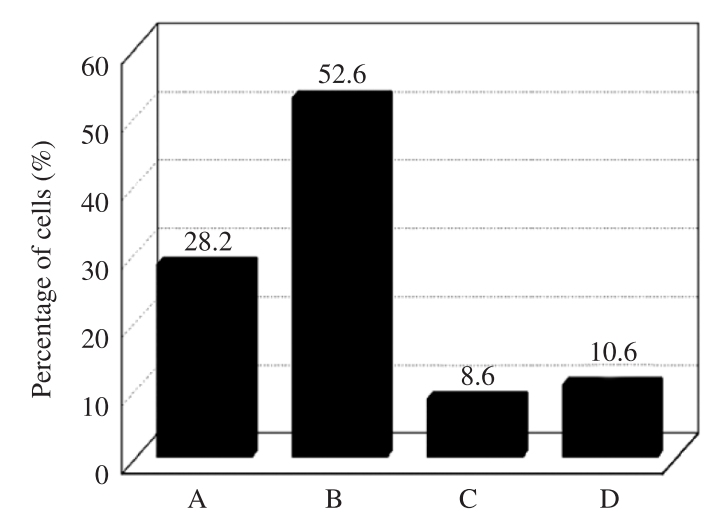

(a) processes: $85.8 \%$ for the former and $85.7 \%$ for the $\mathrm{n}^{+} \mathrm{pp}^{+}$ manufacturing process.

\section{Fabrication and Characterization of PV Modules}

All the equipments needed to produce PV modules were installed and some of them were developed specifically in Brazil for the pilot plant. PV modules were assembled with 36 cells, a typical device for stand-alone systems.

Laminator and automatic tabber\&stringer were acquired from a typical supplier for European PV industries. The former can laminate modules up to $150 \mathrm{~cm} \times 100 \mathrm{~cm}$ and the tabber\&stringer allows the soldering of the cells. The process of soldering the cells to produce the strings was optimized taking into account the ribbon, the metal paste and the fluxant. To connect string to string, we used a specific mask to allow the alignment of the strings during the soldering process.

Solar cells were encapsulated following the standard of PV industry based on tempered high transmittance glass (3.2 $\mu \mathrm{m}$ thick), EVA (ethylene vinyl acetate) and backsheet. Standard and fast cure EVA were used in the pilot plant and the module lamination-curing process profile, that involves several steps at different temperatures, was optimized to obtain cured EVA film with $90 \%$ of gel content (that means the degree of crosslinking), above the range of $65 \%$ to $80 \%$ accepted to produce long lifetime modules ${ }^{14,15}$. Backsheets based on Tedlar ${ }^{\circledR}$ (38 $\mu \mathrm{m}$ thick), PET $(125 \mu \mathrm{m})$ and primer $(100 \mu \mathrm{m})$ were used, producing good isolation for voltages up to $1000 \mathrm{~V}$. Glass sheets were washed with de-ionized water (resistivity of around $0.2 \Omega . \mathrm{cm}$ ) in a system based on a cascade with three recipients.

Anodized aluminum frame was designed and produced in Brazil and was manually assembled by using a pneumatic tool, rivets and silicone (specifically for PV purpose) to seal the edges. Junction box with two diodes, each protecting two strings of nine cells, was attached to the module rear face by using silicone. All modules received a label (bar code) with information about solar cells and materials used. Figure 10 presents a PV module developed and fabricated in the pilot plant.

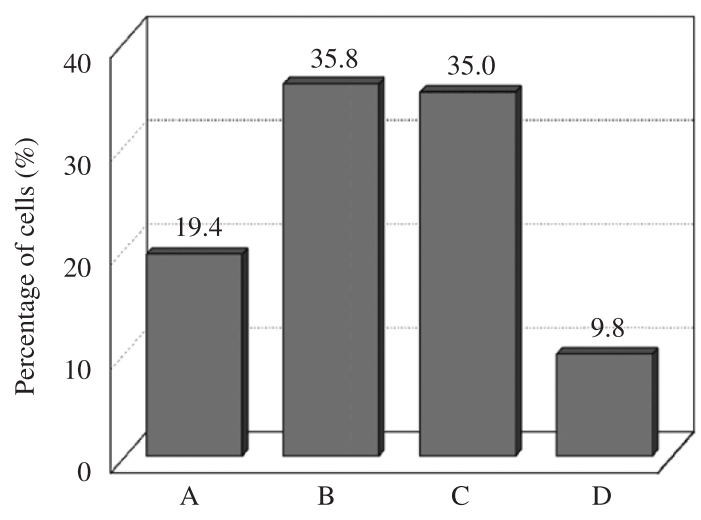

(b)

Figure 8. Distribution of solar cells following the classification based on the JSC and FF for a) $n^{+} \mathrm{pn}^{+}$and b) $\mathrm{n}^{+} \mathrm{pp}^{+}$devices. 


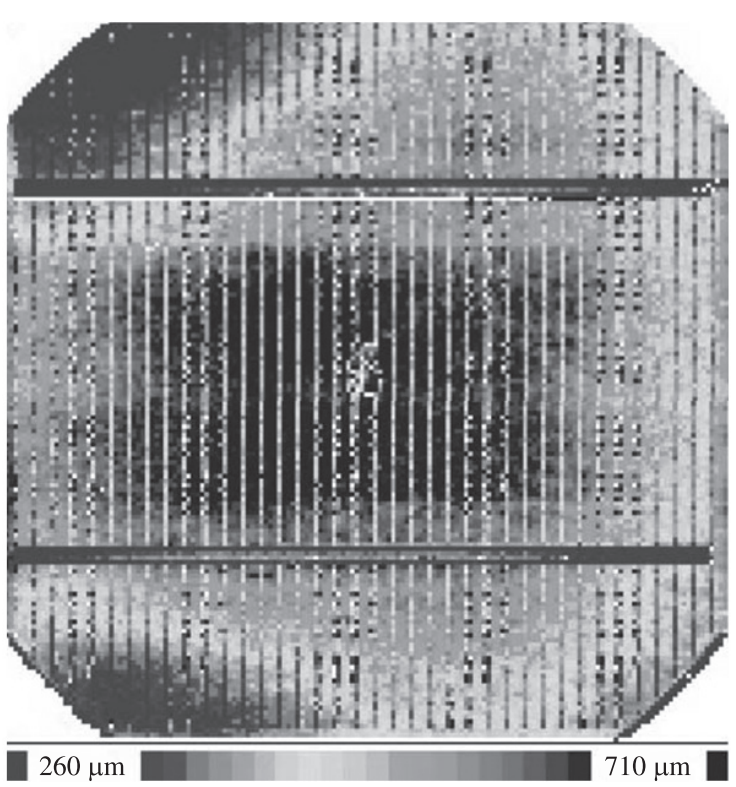

Figure 9. Distribution of minority carrier diffusion length in cells with BSF.

After implementing the pilot line for producing modules, 200 PV modules were produced and characterized under standard conditions (1000 W.m ${ }^{-2}$, AM1.5G, $\left.25^{\circ} \mathrm{C}\right)$, by using a flash solar simulator with flash time of $10 \mathrm{~ms}$. Solar simulator was calibrated with a PV module previously calibrated in the European Solar Test Installation (ESTI), Joint Research Center - European Community, Italy. Besides to measure the I-V curve of all modules, three modules were submitted to the electrical insulation test, twist test and mechanical load test, according to the IEC $61215^{16,17}$. Smaller prototypes were submitted to thermal cycling and salt mist test ${ }^{18}$. In all procedures, prototypes were approved.

Table 4 and Table 5 present the average values of $\mathrm{V}_{\mathrm{OC}}$, short-circuit current $\left(\mathrm{I}_{\mathrm{SC}}\right), \mathrm{FF}$, module efficiency $\left(\eta_{\mathrm{Mod}}\right)$, maximum power point power $\left(\mathrm{P}_{\mathrm{mpp}}\right)$, maximum power point voltage $\left(\mathrm{V}_{\mathrm{mpp}}\right)$ and maximum power point current $\left(\mathrm{I}_{\text {mpp }}\right)$ for modules fabricated with $\mathrm{n}^{+} \mathrm{pn}^{+}$and $\mathrm{n}^{+} \mathrm{pp}^{+}$solar cells with different classes. By using the former cells, $94 \mathrm{PV}$ modules were produced, achieving the average power of $(28.3 \mathrm{~W} \pm 2.5 \%)$. Others 106 modules were manufactured with $\mathrm{n}^{+} \mathrm{pp}^{+}$cells and the average power was $(34.2 \mathrm{~W} \pm 2.6 \%)$. Low deviation remarks the high reproducibility of the processes developed. It is worth to mention that for $\mathrm{n}^{+} \mathrm{pn}^{+}$modules, A-B class cells do not result in modules with different power, so that this level of classification is not needed. Modules produced with class $\mathrm{A}$ and $\mathrm{n}^{+} \mathrm{pp}^{+}$cells presented higher electric power than that fabricated with class B cells mainly due to the $\mathrm{I}_{\mathrm{SC}}$. PV modules assembled with cells classified as A, B and C had similar FF, despite class $\mathrm{C}$ cells presented lower FF than the other two classes. From this result, we can conclude that the low FF is due to the high series resistance of the busbar and this problem was solved by soldering the ribbon. Due to the low quantity of class D cells, modules were not fabricated with these cells.

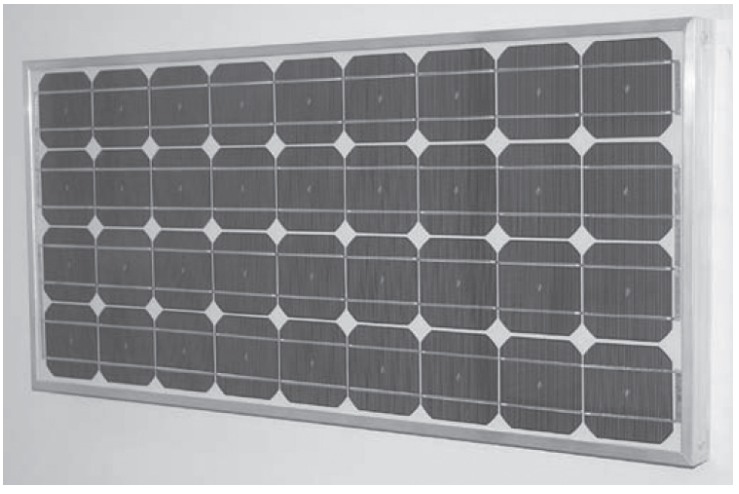

Figure 10. PV module fabricated in the pilot plant.

Table 4. Electrical characteristics of the PV modules fabricated with cells without BSF $\left(\mathrm{n}^{+} \mathrm{pn}^{+}\right)$.

\begin{tabular}{ccll}
\hline Class & $\mathbf{A}$ & \multicolumn{1}{c}{ B } & All \\
\hline Number & $\mathbf{5 2}$ & $\mathbf{4 2}$ & $\mathbf{9 4}$ \\
\hline $\mathrm{P}_{\text {mpp }}(\mathrm{W})$ & $28.4 \pm 0.6$ & $28.3 \pm 0.7$ & $28.3 \pm 0.7$ \\
$\eta_{\text {Mod }}(\%)$ & $10.0 \pm 0.2$ & $10.0 \pm 0.3$ & $10.0 \pm 0.2$ \\
$\mathrm{~V}_{\text {oC }}(\mathrm{V})$ & $19.7 \pm 0.1$ & $19.6 \pm 0.2$ & $19.7 \pm 0.2$ \\
$\mathrm{I}_{\mathrm{SC}}(\mathrm{A})$ & $1.98 \pm 0.01$ & $1.96 \pm 0.01$ & $1.97 \pm 0.01$ \\
$\mathrm{FF}$ & $0.73 \pm 0.01$ & $0.73 \pm 0.02$ & $0.73 \pm 0.02$ \\
$\mathrm{~V}_{\text {mpp }}(\mathrm{V})$ & $15.7 \pm 0.2$ & $15.7 \pm 0.2$ & $15.7 \pm 0.2$ \\
$\mathrm{I}_{\text {mpp }}(\mathrm{A})$ & $1.80 \pm 0.02$ & $1.79 \pm 0.02$ & $1.79 \pm 0.02$ \\
\hline
\end{tabular}

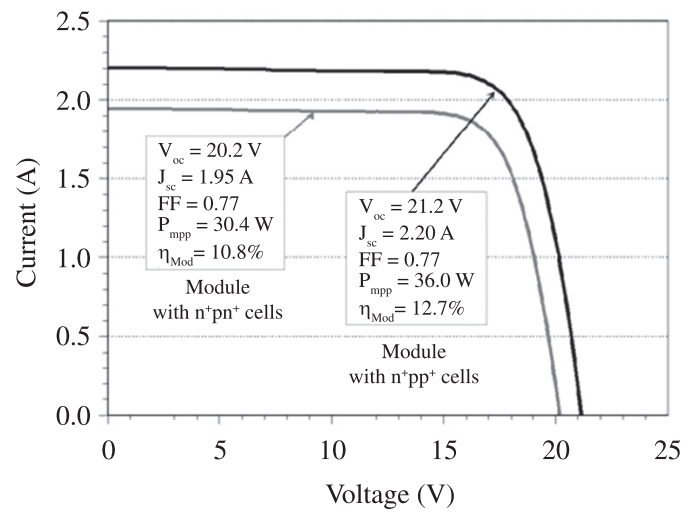

Figure 11. I-V characteristics of best PV modules assembled with $\mathrm{n}^{+} \mathrm{pn}^{+}$and $\mathrm{n}^{+} \mathrm{pp}^{+}$cells. Measurements were carried out at standard conditions with a flash solar simulator.

In the Figure 11, I-V characteristics of the best modules are presented. The efficiencies achieved were of $10.8 \%$ and $12.7 \%$ for $\mathrm{n}^{+} \mathrm{pn}^{+}$and $\mathrm{n}^{+} \mathrm{pp}^{+}$cells, respectively. Both kinds of modules presented very high fill factor, confirming the optimum process of soldering cells and strings. Efficiency of PV modules with $\mathrm{n}^{+} \mathrm{pp}^{+}$cells are similar to that of best commercial small modules with nominal power lower than $50 \mathrm{~W}^{19}$. Taking into account the results presented in Figure 11 for modules produced in the pilot plant, we can estimate the efficiency of higher area modules. For example, for a module with 72 pseudo-square cells and with an area of 
Table 5. Electrical characteristics of the PV modules fabricated with cells with BSF $\left(\mathrm{n}^{+} \mathrm{pp}^{+}\right)$.

\begin{tabular}{lcccc}
\hline Class & A & B & C & All \\
\hline Number & $\mathbf{1 6}$ & $\mathbf{5 5}$ & $\mathbf{3 5}$ & $34.7 \pm 1.0$ \\
\hline $\mathrm{P}_{\text {mpp }}(\mathrm{W})$ & $34.9 \pm 0.9$ & $34.3 \pm 0.6$ & $11.9 \pm 0.4$ & $12.1 \pm 0.3$ \\
$\eta_{\text {Mod }}(\%)$ & $12.4 \pm 0.2$ & $2.2 \pm 0.2$ & $20.8 \pm 0.2$ & $2.12 \pm 0.05$ \\
$\mathrm{~V}_{\mathrm{OC}}(\mathrm{V})$ & $21.0 \pm 0.2$ & $2.14 \pm 0.03$ & $0.768 \pm 0.007$ \\
$\mathrm{I}_{\mathrm{SC}}(\mathrm{A})$ & $2.16 \pm 0.03$ & $0.768 \pm 0.007$ & $17.0 \pm 0.2$ \\
$\mathrm{FF}$ & $0.769 \pm 0.008$ & $17.1 \pm 0.2$ & $1.98 \pm 0.04$ & $0.768 \pm 0.007$ \\
$\mathrm{~V}_{\text {mpp }}(\mathrm{V})$ & $17.2 \pm 0.1$ & $2.01 \pm 0.04$ & $17.1 \pm 0.2$ \\
$\mathrm{I}_{\mathrm{mpp}}(\mathrm{A})$ & $2.03 \pm 0.04$ & & $2.00 \pm 0.04$ \\
\hline
\end{tabular}

$0.52 \mathrm{~m}^{2}$, keeping the average fill factor of the best modules produced at pilot line, efficiency can rise to $13.7 \%$, similar to the average crystalline silicon module efficiency of larger devices applied to grid connected systems.

\section{Conclusions}

At the first time a complete production line, from cells to modules, was established at a university campus in Brazil, allowing the development of industrial processes to produce silicon solar cells and PV modules as well as the preparation of qualified human resources for PV industries, combining education, research and industrial development. Furthermore, the infrastructure of the pilot plant can support PV fabs that will start-up in Brazil. Each processing step of both solar cell fabrication sequences was optimized and more than 12,000 solar cells and 200 PV modules were manufactured. Simplified solar cells based on only one diffusion step achieved efficiencies up to $13.4 \%$ and small PV modules of $10.8 \%$ were produced. Solar cells with BSF region reached the efficiency of $16.1 \%$ and the $12.7 \%$

\section{References}

1. Brazilian Energy Balance 2011 - Year 2010. Rio de Janeiro: Empresa de Pesquisa Energética, EPE; 2011. 266 p.

2. Prado TGF, Oliveira MAG and Camargo, IMT. The Brazilian Renewable Energy Incentive Program - The Second Phase of the PROINFA: Assessing Policy Efficiency and Barriers in Long-term Scenarios. In: Proceedings of the IEEE Energy 2030; 2008; Atlanta. IEEE; 2008. p. 1-6.

3. Rossel AD and Hering G. Land of the future? Brazil has lots of samba and sun but not a lot of PV - yet. Photon International. 2011; 1:14-22.

4. Duerinckx F, Frisson F, Michiels PP, Choulat P and Szlufcik J. Towards highly efficient industrial cells and modules from multicrystalline silicon wafers. In: Proceedings of the 17th European Photovoltaic Solar Energy Conference; 2001; Munich. WIP; 2001. p.1375-1378.

5. Biro D, Preu R, Glunz SW, Rein S, Rentsch J, Emanuel G et al. PV-TEC: Photovoltaic technology evaluation center - design and implementation of a production research unit. In: Proceedings of the 21st European Photovoltaic Solar Energy Conference; 2006; Dresden, Germany. WIP; 2006. p. 621-624. efficient solar modules were fabricated. The yield of solar cell fabrication was of $86 \%$ and standard deviation of the module nominal power was of around $2.5 \%$, which denotes the high reproducibility of the developed processes.

Cells with Al-BSF presented higher efficiency but with larger variation mainly of the short-circuit current, causing a wide range of average efficiencies, from $14.0 \%$ to $14.9 \%$. PV modules produced with this kind of cells presented fill factor higher than the value measured in the solar cells and this result was not observed in $\mathrm{n}^{+} \mathrm{pn}^{+}$devices.

\section{Acknowledgements}

The financial supports by the Brazilian financing agency FINEP (Financiadora de Estudos e Projetos), CEEE (Companhia Estadual de Energia Elétrica), ELETROSUL (Eletrosul Centrais Elétricas S. A.), PETROBRAS (Petróleo Brasileiro S. A.) and CNPq (Conselho Nacional de Desenvolvimento Científico e Tecnológico) are gratefully acknowledged. The authors would like to thank the staff of NT-Solar/PUCRS engaged to process silicon solar cells.
6. Solar Energy Research Institute of Singapore - SERIS. Annual Report 2010. Available from: <http://www.seris.sg > Access in: 05/01/12.

7. National Renewable Energy Laboratory. NREL to help four start-ups ramp up solar energy. Available from: <http:// www.nrel.gov/news/press/2011/1580.html?print>. Access in: $12 / 04 / 12$.

8. Moehlecke A, Zanesco I, Souza JP, Boudinov H and Cañizo C. Low cost silicon solar cell process based on gettering. In: Proceedings of the 17th European PV Solar Energy Conference; 2001; Munich, Germany. WIP; 2001. p. 1873-1876.

9. Kern W. Handbook of Semiconductor Wafer Cleaning Technology. New Jersey: Noyes Publications; 1993. 623 p.

10. Gutiérrez R, Jimeno JC, Hernando F, Recart F and Bueno G. Evaluation of standard screen printed solar cells. In: Proceedings of the 13th European PV Solar Energy Conference; 1995; Nice, France. WIP; 1995. p. 1508-1511.

11. Vásquez C, Alonso J, Vásquez MA, Caballero LJ, Romero $\mathrm{R}$ and Ramos-Barrado JR. Efficiency of commercial Cz-Si solar cell with a shallow emitter. Materials Science and 
Engineering B. 2010; 172:43-49. http://dx.doi.org/10.1016/j. mseb.2010.04.015

12. Shi Z, Wenham S and Ji J. Mass production of the innovative PLUTO solar cell technology. In: Proceedings of the 34th IEEE Photovoltaic Specialists Conference; 2009; Philadelphia. IEEE; 2009. p.1922-1926. http://dx.doi.org/10.1109/ PVSC.2009.5411566

13. Ly M, Eberhardt D, Filomena GZ, Moehlecke A and Zanesco I. Impact of metal grid firing on antireflection coatings. In: Proceedings of the 22th European Photovoltaic Solar Energy Conference and Exhibition; 2007; Milan, Italy. WIP; 2007. p. 1532-1534.

14. Czanderna AW and Pern FJ. Encapsulation of PV modules using ethylene vinyl acetate copolymer as a potant: a critical review. Solar Energy Materials and Solar Cells. 1996; 43:101-181. http://dx.doi.org/10.1016/0927-0248(95)00150-6

15. Agroui K, Belghachi A, Collins G and Farenc J. Quality control of EVA encapsulant in photovoltaic module process and outdoor exposure. Desalination. 2007; 209:1-9. http:// dx.doi.org/10.1016/j.desal.2007.04.001

16. Galdino MA et al. The Brazilian programme for labeling photovoltaic systems. In: Proceedings of the 20th European Photovoltaic Solar Energy Conference; 2005; Barcelona, Spain. WIP; 2005. p.3199-3202.

17. International Standard. IEC 61215: Crystalline silicon terrestrial photovoltaic (PV) modules - Design qualification and type approval. IEC; 1993.

18. Reis Júnior SLS, Moehlecke A and Zanesco I. Analysis of materials and techniques for photovoltaic module encapsulation. In: Proceedings of the 24th European Photovoltaic Solar Energy Conference and Exhibition; 2009; Hamburg, Germany. WIP; 2009. p. 3502-3504.

19. Solar Module-Data. Photon Info. Available from: <http:// www.photon.info/photon_site_db_solarmodule-en. photon?ActiveID=1242>. Access in: 16/01/12. 